JEL Classification: M21

UDC 658.51

DOI: $10.30857 / 2415-3206.2019 .2 .2$

\section{METHOD OF ASSESSMENT OF ENTERPRISE READY FOR OUTSOURCING IMPLEMENTATION}

O. MORHULETS ${ }^{1}$, O. NYSHENKO ${ }^{1}$

${ }^{1}$ Kyiv National University of Technologies and Design, Ukraine
Introduction. Today Ukrainian enterprises operate under difficult economic conditions, which have developed against the background of the constant increase in the cost of raw materials, energy tariffs, changing geopolitical situation, difficult political situation in the country, which is why most of the enterprises struggle for survival instead of development. Against this background, competition with foreign producers is aggravated, accompanied by a narrowing of the domestic market.

Given the complex economic conditions of Ukrainian enterprises, their success today depends on the effectiveness of management in these conditions. Businesses require a modern business process management tool designed to adapt to new challenges and find ways to mitigate the effects of external factors. The economic development of the enterprise is conditioned by the progress of information technologies, the emergence of innovative forms of management, new principles of division of labor, etc. Changes in the management of business entities now require new scientific and methodological approaches, from which the enterprise is regarded as a set of business processes. One of the modern ways of improving the business system is the attraction of external contractors, which is solved by the introduction of outsourcing and allows to increase the efficiency of the enterprise and its competitiveness in the market.

Hypothesis. Assessing the readiness of an enterprise to implement outsourcing provides validity of the management decision on outsourcing of business processes and helps to increase the efficiency of utilization of the enterprise's potential.

The purpose of this article is to develop a methodological approach to assessing the degree of readiness of the enterprise to implement business process outsourcing to improve the efficiency of the enterprise in the current economic environment and to strengthen its competitive position in the domestic and international markets.

Research methods. The methodological basis of the research is a system of general scientific and special methods, the main of which are: dialectical approach, methods of classification and systematization, analysis and synthesis, statistical and logical analysis, concretization, expert assessments and economic and mathematical modeling.

Results. A methodical approach to assessing the degree of readiness of an enterprise to use outsourcing in business process management is offered, which, unlike the existing ones, makes it possible to substantiate the outsourcing decision taking into account the existing potential of the enterprise with a greater degree of certainty.

Conclusions. As a result of the research, the problem of scientific and methodological substantiation of the enterprise's readiness for implementation of business process outsourcing at the enterprise was solved. This methodological approach enables the management of a number of indicators and the appropriate scale to assess the degree of readiness - the sufficiency of the enterprise's capacity to implement outsourcing and to overcome the risks associated with it. The proposed approach enhances the effectiveness of the management decision to outsource, is versatile and can be used in the practice of any enterprise that plans or already uses outsourcing in business.

Keywords: outsourcing; business processes; enterprise management; management decisions; decision substantiation. 
JEL Classification: M21

УДК 658.51

DOI: $10.30857 / 2415-3206.2019 .2 .2$
МЕТОДИКА ОЦІНЮВАННЯ ГОТОВНОСТІ ПІДПРИЕМСТВА ДО ВПРОВАДЖЕННЯ АУТСОРСИНГУ

\author{
О. МОРГУЛЕЦЬ ${ }^{1}$, О. НИШЕНКО ${ }^{1}$ \\ ${ }^{1}$ Київський національний університет технологій \\ та дизайну, Украӥна
}

Вступ. Підприємства України сьогодні господарюють в непростих економічних умовах, що склались на фоні постійного зростання вартості сировини, тарифів на енергоносіїв, зміни геополітичної кон'юнктури, складної політичної ситуації в країні, внаслідок чого більшість підприємств замість розвитку борються за виживання. На фоні цієї ситуації загострюється конкурентна боротьба 3 іноземними виробниками, що супроводжується звуженням внутрішнього ринку збуту.

Зважаючи на складні умови господарювання українських підприємств їх успіх сьогодні залежить від ефективності управління в цим умовах. Для суб'єктів господарювання необхідним $\epsilon$ сучасний інструментарій управління бізнес-процесами направлений на адаптацію до нових викликів, а також на пошук шляхів щодо полегшення наслідків негативного впливу чинників зовнішнього середовища. Економічний розвиток підприємства визначається прогресом IT-технологій, появою інноваційних форм господарювання, сучасних принципів розподілу праці, тощо. Зміни в системі управління суб'єктів господарювання вимагає нових науково-методичних підходів, в розрізі яких підприємство розглядається як сукупність бізнес-процесів. Сучасним напрямком удосконалення бізнес-системи $\epsilon$ залучення зовнішніх контрагентів, що реалізується шляхом впровадження аутсорсингу та дає можливість підвищити ефективність діяльності підприємства та його конкурентоспроможність на ринку.

Гіпотеза дослідження. Оцінювання готовності підприємства до впровадження аутсорсингу забезпечує обгрунтованість управлінського рішення щодо аутсорсингу бізнес-процесів та сприяє підвищенню ефективності використання потенціалу підприємства.

Метою даної статті $\epsilon$ розробка методичного підходу до оцінювання ступеня готовності підприємства щодо впровадження аутсорсингу бізнес-процесів для підвищення ефективності діяльності підприємства в сучасних умовах господарювання та посилення його конкурентної позиції на вітчизняному та міжнародному ринку.

Методи дослідження. Методичною основою дослідження $є$ система загальнонаукових та спеціальних методів, основними 3 яких $\epsilon$ : діалектичний підхід, методи класифікації i систематизації, аналізу і синтезу, статистичного і логічного аналізу, конкретизації, експертних оцінок та економіко-математичного моделювання.

Результати. Запропоновано методичний підхід до оцінювання ступеня готовності підприємства до використання аутсорсингу в управлінні бізнес-процесами, що на відміну від існуючих дає можливість 3 більшим ступенем достовірності обгрунтувати рішення щодо аутсорсингу з врахуванням наявного потенціалу підприємства.

Висновки. В результаті проведеного дослідження вирішено завдання науковометодичного обгрунтування готовності підприємства до впровадження аутсорсингу бізнес-процесів на підприємстві. Такий методичний підхід дає можливість керівництву за низкою показників та відповідною шкалою оцінити ступінь готовності - достатності потенціалу підприємства до впровадження аутсорсингу та подолання ризиків, які 3 цим пов'язані. Запропонований підхід посилює ефективність управлінського рішення щодо впровадження аутсорсингу, $\epsilon$ універсальним i може бути використаний у практичній діяльності будь-яких підприємств, які планують або уже використовують аутсорсинг в господарській діяльності.

Ключові слова: аутсорсинг; бізнес-процеси; управління підприємством; управлінські рішення; обгрунтування рішень. 


\section{Formulation of the problem and its relation to important scientific and} practical tasks. Today Ukrainian enterprises operate under difficult economic conditions, which have developed against the background of the constant increase in the cost of raw materials, energy tariffs, changing geopolitical situation, difficult political situation in the country, which is why most of the enterprises struggle for survival instead of development. Against this background, competition with foreign producers is aggravated, accompanied by a narrowing of the domestic market.

Given the complex economic conditions of Ukrainian enterprises, their success today depends on the effectiveness of management in these conditions. Businesses require a modern business process management tool designed to adapt to new challenges and find ways to mitigate the effects of external factors. The economic development of the enterprise is conditioned by the progress of information technologies, the emergence of innovative forms of management, new principles of division of labor, etc. Changes in the management of business entities now require new scientific and methodological approaches, from which the enterprise is regarded as a set of business processes. One of the modern ways of improving the business system is the attraction of external contractors, which is solved by the introduction of outsourcing and allows to increase the efficiency of the enterprise and its competitiveness in the market.

Analysis of recent publications on the problem and unresolved parts of the study. Theoretical, methodological and practical aspects of business process outsourcing management have been reflected in the scientific works of scientists, including: E. Anderson, B. Trinkle [1]; J. Arlbjorn, A. Haug [2]; P. Barrar, R. Gervais [3]; J-L. Bravard, R. Morgan [4]; M. Cook [5]; M. Corbett [6]; J. Halvey, B. Melby [7]; H. Harrington, E. Esseling [8]; M. Heric, B. Singh [9]; J. Heywood [10]; R. Mclvor [12, 13]; M. Schniederjans [14]; A. Shtub, R. Karni [15]; L. Willcocks, A. Craig [16]; B. Andersen [17]; O. Didukh [18]; N. Zavalko [19]; S. Kalendjan [20]; D. Lanskaya [21]; I. February [22]; N. Pedchenko [23]; I. Rudaya [24]; S. Saifiev [25] and others.

The analysis of scientific works related to the mentioned topic indicates that some issues of outsourcing of business processes of the enterprise remain open, in particular regarding the substantiation of the management decision to implement the outsourcing of business processes of the enterprise as a tool for improving the efficiency of economic activity. The presented scientific results of the research are based on the generalization of the findings obtained by domestic and foreign scientists and used to develop a methodological approach to assess the readiness of the enterprise to outsource business processes.

The purpose of the study is to develop a methodological approach to assessing the degree of readiness of the company to implement outsourcing of business processes to improve the efficiency of the enterprise in the current 
economic environment and strengthen its competitive position in the domestic and international markets. The object of the study is the process of substantiation of the management decision on the use of business process outsourcing at the enterprise.

Outline of the main results and their justification. In the article outsourcing is considered as a tool for managing the business processes of the enterprise, which aims at improving the efficiency of the enterprise by transferring non-core business processes to the outsourcer company, which assumes responsibility for their execution in favor of the customer enterprise.

The rapid process of formation and development of outsourcing as a type of entrepreneurial activity was facilitated by the fact that enterprises that used the services of outsourcers receive a number of advantages, namely: the ability to focus on their core business; ensuring proper quality of execution of non-core processes; opportunity to realize diversification strategy at the expense of unleashed potential; redistribution and reduction of risks; cost savings; access to new technologies and knowledge; management system optimization; increasing investment attractiveness and more.

Management decision making on outsourcing as a tool for improving the efficiency of an enterprise is a multifaceted and complex process that requires the involvement of human, financial and information resources and the development of a methodological approach to substantiate outsourcing decisions.

The methodological approach to the substantiation of the decision on outsourcing of business processes of the enterprise according to the authors should include the analysis of prerequisites for the emergence of managerial situation and the need to make the appropriate decision; choice of business process and substantiation of expediency of its outsourcing; assessment of the enterprise's willingness to use outsourcing; assessment of the level of outsourcing activation; forecasting changes in the profitability of an enterprise after outsourcing is activated. The article proposes to consider the method of estimating the degree of readiness of the enterprise for implementation of business process outsourcing.

Therefore, one of the mandatory steps in the outsourcing decision making process is to evaluate the degree of readiness of the enterprise to outsource certain business processes for outsourcing. The criteria for evaluating the enterprise's readiness for outsourcing are based on the criteria proposed by the authors, namely:

1) previous positive outsourcing experience;

2) transparency of the enterprise;

3) the existence of an effective environmental monitoring system;

4) the contents of the main business processes are isolated and described; 
5) the content and ancillary content of the supporting business processes is identified and described;

6) development strategy;

7) availability of full-time qualified change management specialists;

8) existence of an effective controlling system;

9) availability of a multi-level quality management system;

10) the availability of quality and effective legal support;

11) innovative orientation of enterprise development;

12) the existence of a corporate social responsibility system.

To assess the readiness of the enterprise for outsourcing, it is proposed by the expert method to evaluate the degree of manifestation of each criterion in the activity of the enterprise on the following scale [22]:

"5" - if the criterion is fully detected;

"4" - if the criterion is not completely;

"3" - if the criterion is weak;

"2" - if the criterion is not detected.

The weighted average assessment of the degree of readiness of the company for outsourcing is suggested by the formula:

$$
S=\frac{1}{m \cdot n} \sum_{i=1}^{m} k_{i} \sum_{j=1}^{n} S_{i j},
$$

where $S$ - the enterprise's readiness for outsourcing;

$S_{i j}$ - the point evaluation of the $j$-th expert of the degree of manifestation of the $i$-th criterion;

$n$ - number of experts;

$m$ - number of criteria considered;

$k_{i}$ - coefficient of importance of the $i$-th criterion, determined by the rule:

$k_{i}=\left\{\begin{array}{c}1-\text { if the } i-t h \text { criterion is "less important", } \\ 2-\text { if the } i-\text { th criterion is "important", } \\ 3-\text { if the } i-\text { th criterion is "very important" }\end{array}\right.$

To determine the readiness of the enterprise to implement outsourcing on the basis of a certain weighted average score, an appropriate scale is proposed (Figure 1). 


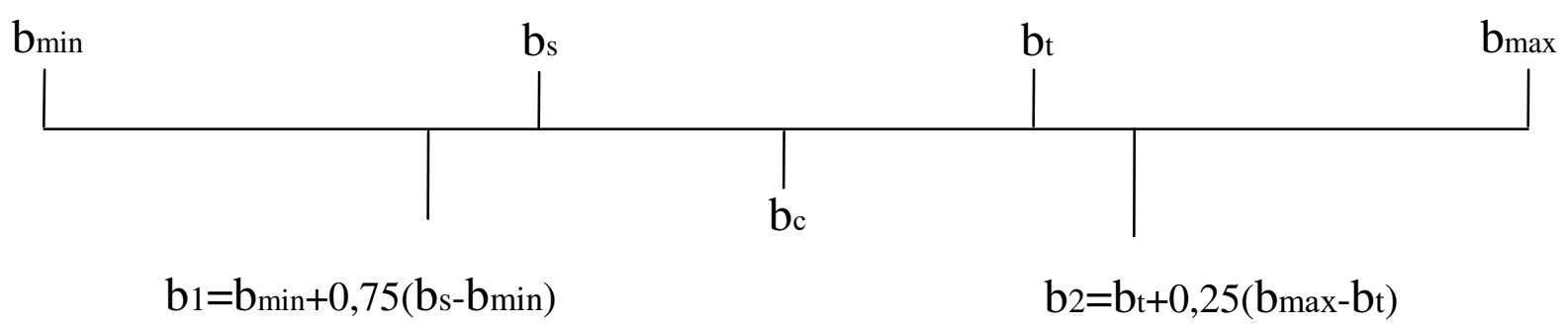

Source: [22; 23].

\section{Figure 1. The scale of determining the degree of readiness of the company for the implementation of outsourcing}

The characteristics of the degree of readiness of the enterprise for outsourcing implementation are formalized as follows:

- very high if the weighted average score falls into the interval $\left(b_{t}+0,25\left(b_{\max }-b_{t}\right) ; b_{\max }\right)$, where $b_{\max }$ - weighted average, which corresponds to the case of full compliance of all 12 criteria of the optimal state - "5", $b_{t}$ - weighted average, which corresponds to the case of incomplete compliance of all 12 criteria to the optimal state - "4";

- high, if the obtained average weighted score falls on the interval $\left(b_{c} ; b_{t}+0,25\left(b_{\max }-b_{t}\right)\right)$, where $b_{c}=\frac{b_{\min }+b_{\max }}{2}$;

- moderate if the weighted average score falls on the interval $\left(b_{\min }+0,75\left(b_{s}-b_{\min }\right) ; b s\right)$, where $b_{\min }$ - weighted average, which corresponds to the case of complete mismatch of all 12 criteria of the optimal state - "2", bs weighted average, which corresponds to the case of weak conformity of all 12 criteria to the optimal state - "3";

- low, if the average weighted score falls on the interval $\left(b_{\min } ; b_{\min }+0,75\left(b_{s}-b_{\min }\right)\right)$.

To approve the proposed methodological approach to assess the degree of readiness of the enterprise for outsourcing according to the data of the garment industry enterprise, namely JSC Khmelnytsky Garment Factory Lileya, empirical studies were conducted. The results of the expert evaluation of the readiness of JSC Khmelnytsky Garment Factory Lileya for outsourcing are presented in Table 1. 
Table 1

\section{Willingness of PJSC Khmelnytsky Garment Factory Lileya} for outsourcing implementation

\begin{tabular}{|c|c|c|c|c|c|c|c|c|c|c|c|c|}
\hline \multirow{3}{*}{ 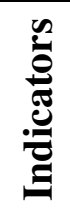 } & \multicolumn{12}{|c|}{ Assessment of the degree of manifestation of indicators } \\
\hline & \multicolumn{11}{|c|}{ experts } & $\begin{array}{l}\text { The importance factor } \\
\text { of the } i \text {-th indicator }\end{array}$ \\
\hline & $S_{1}$ & $S_{2}$ & $S_{3}$ & $S_{4}$ & $S_{5}$ & $S_{6}$ & $S_{7}$ & $S_{8}$ & $S_{9}$ & $S_{10}$ & $S_{11}$ & $k_{i}$ \\
\hline 1 & 5 & 5 & 5 & 5 & 5 & 5 & 5 & 5 & 5 & 5 & 5 & 1 \\
\hline 2 & 5 & 5 & 5 & 5 & 5 & 5 & 5 & 5 & 5 & 5 & 5 & 2 \\
\hline 3 & 5 & 5 & 5 & 5 & 5 & 5 & 5 & 5 & 5 & 5 & 5 & 3 \\
\hline 4 & 5 & 5 & 5 & 5 & 5 & 5 & 5 & 5 & 5 & 5 & 5 & 3 \\
\hline 5 & 5 & 5 & 5 & 5 & 5 & 5 & 5 & 5 & 5 & 5 & 4 & 3 \\
\hline 6 & 5 & 5 & 5 & 5 & 5 & 5 & 5 & 5 & 5 & 5 & 5 & 3 \\
\hline 7 & 5 & 5 & 4 & 5 & 5 & 5 & 5 & 5 & 4 & 5 & 4 & 2 \\
\hline 8 & 5 & 5 & 5 & 5 & 5 & 5 & 5 & 5 & 4 & 5 & 5 & 2 \\
\hline 9 & 5 & 5 & 5 & 5 & 4 & 5 & 5 & 5 & 5 & 5 & 4 & 3 \\
\hline 10 & 5 & 5 & 4 & 5 & 5 & 5 & 5 & 5 & 5 & 5 & 5 & 3 \\
\hline 11 & 5 & 5 & 5 & 5 & 5 & 5 & 5 & 5 & 5 & 5 & 5 & 3 \\
\hline 12 & 5 & 5 & 5 & 5 & 4 & 5 & 5 & 5 & 5 & 5 & 5 & 1 \\
\hline$\sum_{i=1}^{12}$ & 60 & 60 & 58 & 60 & 58 & 60 & 60 & 60 & 58 & 60 & 57 & 29 \\
\hline
\end{tabular}

Source: compiled by the authors

For JSC Khmelnytsky Garment Factory Lileya: the coefficient of concordance is 0,886 ; the number of considered indicators $(m)-12$ (according to Table 1); number of experts (n) -11 .

$$
\begin{gathered}
\sum_{i=1}^{12} k_{i}=29 \\
\sum_{j=1}^{11} S_{i j}=60+60+58+60+58+60+60+60+58+60+57=651
\end{gathered}
$$

- weighted average readiness of PJSC Khmelnytsky Garment Factory Lileya for outsourcing is:

$$
S=\frac{1}{12 \cdot 11} * 29 * 651=143,02
$$

For a general scale, the number of experts is $\mathrm{n}=1, \sum_{i=1}^{m} k_{i}=29$.

For $b_{\max }$ the overall score evaluation of indicators will be:

$$
\sum_{j=1}^{n} S_{i j}=12 * 5=60
$$

For $b_{n p}$ the overall score evaluation of indicators will be: 


$$
\sum_{j=1}^{n} S_{i j}=12 * 4=48 .
$$

For $b_{s l}$ the overall score evaluation of indicators will be:

$$
\sum_{j=1}^{n} S_{i j}=12 * 3=36
$$

For $b_{\min }$ the overall score evaluation of indicators will be:

$$
\sum_{j=1}^{n} S_{i j}=12 * 2=24
$$

Then,

$$
\begin{gathered}
b_{\min }=\frac{1}{12 \cdot 1} * 29 * 24=58 ; \\
b_{s l}=\frac{1}{121} * 29 * 36=87 ; \\
b_{n p}=\frac{1}{121} * 29 * 48=116 ; \\
b_{\text {maa }}=\frac{1}{12 \cdot 1} * 29 * 60=145 ; \\
b_{1}=58+0,75(87-58)=79,75 ; \\
b_{c p}=\frac{58+145}{2}=101,50 ; \\
b_{2}=116+0,25(145-116)=123,25
\end{gathered}
$$

We present a general scale of weighted average scores of indicators of the indicators, indicating the received average weighted readiness score $(143,02)$ JSC Khmelnytsky garment factory "Lileya" to the implementation of outsourcing (Figure 2), which will finally determine the degree of readiness of the enterprise.

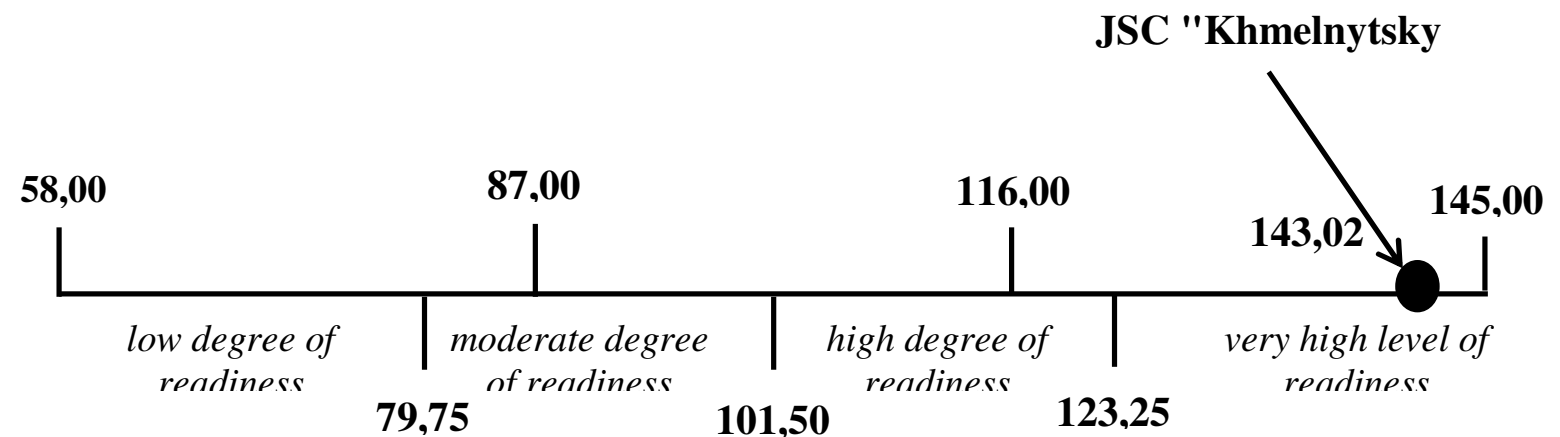

Source: calculated by the authors.

Figure 2. Scale for assessing the readiness of JSC Khmelnytsky Garment Factory Lileya for outsourcing 
To evaluate the degree of readiness of the company according to the calculations, an evaluation scale is proposed (Table 2).

Table 2

The scale of evaluation of the degree of readiness of the enterprise for the implementation of outsourcing

\begin{tabular}{|l|c|l|c|}
\hline Degree & $S$ & \multicolumn{1}{|c|}{ Characteristic } & Recommendations \\
\hline $\begin{array}{l}\text { Very } \\
\text { high }\end{array}$ & $\begin{array}{c}123,25- \\
145,00\end{array}$ & $\begin{array}{l}\text { The enterprise has significant potential to } \\
\text { effectively implement outsourcing as a } \\
\text { management tool and to address all the risks } \\
\text { involved. }\end{array}$ & $\begin{array}{r}\text { Implementation } \\
\text { recommended }\end{array}$ \\
\hline High & $\begin{array}{l}\text { The enterprise has sufficient capacity to effectively } \\
\text { implement outsourcing as a management tool and } \\
\text { to address the major risks involved. }\end{array}$ & $\begin{array}{c}\text { Implementation } \\
\text { recommended }\end{array}$ \\
\hline Moderate & 793,24 & $\begin{array}{l}\text { The enterprise has little potential for effective } \\
\text { outsourcing as a management tool and is unable to } \\
\text { fully address the risks involved. }\end{array}$ & $\begin{array}{c}\text { Implementation is } \\
\text { recommended as an } \\
\text { experiment for one } \\
\text { of the business } \\
\text { processes }\end{array}$ \\
\hline Low & $58,00-$ & $\begin{array}{l}\text { The enterprise lacks the potential to effectively } \\
\text { implement outsourcing as a management tool and } \\
\text { to minimize the risks involved }\end{array}$ & $\begin{array}{c}\text { Implementation is } \\
\text { not recommended }\end{array}$ \\
\hline
\end{tabular}

Source: compiled and calculated by the authors.

According to the above, we can conclude that the sewing enterprise is very willing to outsource the implementation of outsourcing and recommend the development and implementation of outsourcing projects to the management of PJSC Lileja in the near future.

Conclusions and prospects for further research. Thus, as a result of the research, the task of scientific and methodological substantiation of the enterprise's readiness for implementation of business process outsourcing at the enterprise was solved. This methodological approach enables the management of a number of indicators and the appropriate scale to assess the degree of readiness - the sufficiency of the enterprise's capacity to implement outsourcing and to overcome the risks associated with it. The proposed approach enhances the effectiveness of the management decision to outsource, is versatile and can be used in the practice of any enterprise that plans or already uses outsourcing in business.

Prospects for further scientific development in this area should focus on the development of a comprehensive methodological approach to substantiate outsourcing efficiency and practical aspects of its implementation, in particular, the study of outsourcing life cycle and the formation of recommendations for improving the efficiency of outsourcing in managing business processes. 


\section{References}

1. Anderson, E., Trinkle, B. (2005). Outsourcing the Sales Function: The Real Costs of Field Sales. Mason, Ohio: Thomson / South-Western Educational Publishers.

2. Arlbjorn, J.S., Haug, A. (2010). Business process optimization. Denmark: Academica.

3. Barrar, P., Gervais, R. (2006). Global Outsourcing Strategies: An International Reference on Effective Outsourcing Relationships. Hampshire, UK: Gower Publishing Ltd.

4. Bravard, J-L, Morgan, R. (2006). Smarter Outsourcing: An executive guide to understanding, planning and exploiting successful outsourcing relationships. Dorchester, M.A.: Pearson Education Ltd.

5. Cook, M.F. (1999). Outsourcing human resources functions. Strategies for providing enhanced HR services at lower cost. New York, NY: AMACOM.

6. Corbett, M.F. (2004). The Outsourcing Revolution : Why It Makes Sense and How to Do It Right. New York: Kaplan Business.

7. Halvey, J.K., Melby, B.M. (2007). Business process outsourcing: process, strategies and contracts. Hoboken, N.J.: Wiley.

8. Harrington, H.J., Esseling, E.K.C., Van Nimwegen, H. (1998). Business process improvement workbook: Documentation, analysis, design, and management of business process improvement. New York: McGraw-Hill.

9. Heric, M., Singh, B. (2010). Outsourcing Can Do Much More Than Just Cut Costs. Forbes. Retrieved from: https://www.forbes.com/2010/06/ 15/outsourcing-capability-sourcing-leadershipmanaging-bain.html\#6d0aa0af718b.

\section{Література}

1. Anderson E. Outsourcing the Sales Function: The Real Costs of Field Sales / E. Anderson, B. Trinkle. - Mason, Ohio: Thomson / South-Western Educational Publishers, 2005.

2. Arlbjorn J. S. Business process optimization / J. S. Arlbjorn, A. Haug. Denmark: Academica, 2010.

3. Barrar P. Global Outsourcing Strategies: An International Reference on Effective Outsourcing Relationships / P. Barrar and R. Gervais. - Hampshire, UK: Gower Publishing Ltd, 2006.

4. Bravard J.-L. Smarter Outsourcing: An executive guide to understanding, planning and exploiting successful outsourcing relationships / J.-L. Bravard, R. Morgan. - Dorchester, M.A.: Pearson Education Ltd, 2006.

5. Cook M. F. Outsourcing human resources functions. Strategies for providing enhanced HR services at lower cost / M. F. Cook. - New York, NY: AMACOM, 1999.

6. Corbett M. F. The Outsourcing Revolution : Why It Makes Sense and How to Do It Right / M. F. Corbett. New York: Kaplan Business, 2004.

7. Halvey J. K. Business process outsourcing: process, strategies and contracts / J. K. Halvey, B. M. Melby. Hoboken, N.J. : Wiley, 2007.

8. Harrington H. J. Business process improvement workbook: Documentation, analysis, design, and management of business process improvement / H. J. Harrington, E. K. C. Esseling and H. Van Nimwegen. - New York: McGraw-Hill, 1998.

9. Heric M. Outsourcing Can Do Much More Than Just Cut Costs / M. Heric, B. Singh. - Forbes, 2010. - Retrieved from: https://www.forbes.com/2010/06/ 15/outsourcing-capability-sourcingleadership-managingbain.html\#6d0aa0af718b. 
10. Heywood, J.B. (2001). The outsourcing dilemma: The search forcompetitiveness. London: Pearson Education Ltd.

\section{ISO 37500:2014 How a PECB Certified} Outsourcing Manager Certification Can Benefit Your Organization. Retrieved from: https:// pecb.com/whitepaper/iso-375002014-how-a-pecbcertified-outsourcing-manager-certification-canbenefit-your-organization.

12. Mclvor, R. (2005). The Outsourcing Process: Strategies for Evaluation and Management. Cambridge: Cambridge University Press.

13. Mclvor, R. (2010). Global Services Outsourcing. Cambridge: Cambridge University Press.

14. Schniederjans, M.J., Schniederjans, A.M., Schniederjans, D.G. (2005). Outsourcing and Insourcinginan International Context. London: M. E. Sharpe.

15. Shtub, A., Karni, R. (2010). ERP: The Dynamics of Supply Chain and Process Management. New York, NY: Springer.

16. Willcocks, L.P., Craig, A. (2007). The Outsourcing Enterprise: Building Retained Core Capabilities. London: Logica.

17. Andersen, B. (2003). Biznes-protcessy. Instrumenty sovershenstvovaniia [Business processes. Improvement Tools]. Translation from English S.V. Arinichev; Scientific Editors Iu.P. Adler. Moscow: RIA "Standarty i kachestvo". 272 p. [in Russian].

18. Didukh, O.V. (2012). Osnovni vydy autsorsynhu u hospodarskii diialnosti pidpryiemstv [Main types of outsourcing in business activity of enterprises]. Visnyk Khmelnytskoho natsionalnoho universytetu [Bulletin of Khmelnitsky National University], No. 2, Vol. 1, P. 29-33. Retrieved from: http://www.nbuv.gov.ua/old_jrn/Soc_Gum/Vchnu _ekon/2012_2_1/029-033.pdf [in Ukrainian].

19. Zavalko, N.A., Mikhalev, E.O. (2010). Autsorsing kak osnovnoi instrument formirovaniia
10. Heywood J. B. (2001). The outsourcing dilemma: The search for competitiveness / J. B. Heywood. London: Pearson Education Ltd, 2001.

11. ISO 37500:2014 How a PECB Certified Outsourcing Manager Certification Can Benefit Your Organization. Retrieved from: https://pecb.com/whitepaper/iso-37500 2014-how-a-pecb-certified-outsourcingmanager-certification-can-benefit-yourorganization.

12. Mclvor R. The Outsourcing Process: Strategies for Evaluation and Management / R. Mclvor. - Cambridge: Cambridge University Press, 2005.

13. Mclvor R. Global Services Outsourcing / R. Mclvor. - Cambridge: Cambridge University Press, 2010.

14. Schniederjans M. J. Outsourcing and Insourcinginan International Context / M. J. Schniederjans, A. M. Schniederjans and D. G. Schniederjans. - London: M. E. Sharpe, 2005.

15. Shtub A. ERP: The Dynamics of Supply Chain and Process Management / A. Shtub, R. Karni. - New York, NY: Springer, 2010.

16. Willcocks L. P. The Outsourcing Enterprise: Building Retained Core Capabilities / L. P. Willcocks, A. Craig. London: Logica, 2007.

17. Андерсен Б. Бизнес-процессы. Инструменты совершенствования / Б. Андерсен; пер. с англ. С. В. Ариничева; науч. ред. Ю. П. Адлер. - Москва: РИА "Стандарты и качество", 2003. - 272 с. 18. Дідух О. В. Основні види аутсорсингу у господарській діяльності підприємств [Електронний ресурс] / О.В. Дідух // Вісник Хмельницького національного університету. - 2012. - № 2, Т. 1. С. 29-33. - Режим доступу: http://www.nbuv.gov.ua/old_jrn/Soc_Gu $\mathrm{m} / \mathrm{V}$ chnu_ekon/2012_2_1/029-033.pdf. 19. Завалько Н. А. Аутсорсинг как основной инструмент формирования 
setevykh organizatcionnykh struktur [Outsourcing as the main tool for the formation of network organizational structures]. Izvestiia UrGEU [News of Ural State Economic University], No. 5 (31), P. 21-24. Retrieved from: http://cyberleninka.ru/ article/n/autsorsing-kak-osnovnoy-instrumentformirovaniya-setevyh-organizatsionnyh-struktur [in Russian].

20. Kalendzhian, S.O. (2003). Autsorsing i delegirovanie polnomochii $\mathrm{v}$ deiatelnosti kompanii [Outsourcing and delegation of authority in the activities of companies: abstract of the dissertation of a doctor of economical sciences]. Moscow. Retrieved from: http://www.dissercat.com/content/ autsorsing-i-delegirovanie-polnomochii-vdeyatelnosti-kompanii [in Russian].

21. Lanskaia, D.V. Metodologicheskie osnovaniia autsorsinga [The methodological basis of outsourcing]. Nauchnyi zhurnal KubGAU [Scientific journal KubSAU], No.101 (07). Retrieved from: http://ej.kubagro.ru/archive.asp? $\mathrm{n}=101$ [in Russian].

22. Liutyi, I.O., Solodka, O.O. (2009). Bankivskyi marketynh: monohrafiia [Banking marketing: a monograph]. Kyiv: Tsentr uchbovoi literatury. 776 p. [in Ukrainian].

23. Pedchenko, N.S., Yakovenko, T.I. (2016). Naukovo-metodychnyi pidkhid do rozrobky ta vprovadzhennia marketynhovoi stratehii $\mathrm{v}$ diialnist pidpryiemstv reklamnoi haluzi [Scientific-methodical approach to the development and implementation of marketing strategy in the activity of enterprises of the advertising industry]. Biznes inform [Business Inform], No. 7, P. 163-169 [in Ukrainian].

24. Rudaia, I.L. (2009). Autsorsing: metodologiia i praktika: monografiia [Outsourcing: Methodology and Practice: Monograph]. Samara: Universgrupp. 230 p. [in Russian].

25. Saifieva, S.N., Bykadorov, M.A. (2006). Teoreticheskie osnovy i evoliutciia razvitiia autsorsinga [The theoretical foundations and evolution of outsourcing]. Zhurnal ekonomicheskoi teorii [Journal of Economic Theory], No. 3. Retrieved from: http://www.iprras.ru/articles/sajf-bik06-7-a.pdf [in Russian]. сетевых организационных структур [Электронный ресурс] / Н. А. Завалько, Е. О. Михалёв // Известия УрГЭУ. - 2010. № 5 (31). C. 21-24. - Режим доступа: http:// cyberleninka.ru/article/n/autsorsing-kakosnovnoy-instrument-formirovaniyasetevyh-organizatsionnyh-struktur. 20. Календжян С. О. Аутсорсинг и делегирование полномочий в деятельности компаний: автореф. дис. ... д-ра эконом. наук [Электронный ресурс] / С. О. Календжян. - Москва, 2003. - Режим доступа: http://www. dissercat.com/content/autsorsing-i-dele girovanie-polnomochii-v-deyatelnostikompanii.

21. Ланская Д. В. Методологические основания аутсорсинга [Электронный pecypc] / Д. В. Ланская // Научный журнал КубГАУ. - 2014. - № 101 (07). - Режим доступа: http://ej.kubagro.ru/ archive.asp? $\mathrm{n}=101$.

22. Лютий I. O. Банківський маркетинг: монографія / I. О. Лютий, О. О. Солодка. - К.: Центр учбової літератури, 2009. - 776 с.

23. Педченко Н. С. Науковометодичний підхід до розробки та впровадження маркетингової стратегії в діяльність підприємств рекламної галузі / Н. С. Педченко, Т. І. Яковенко // Бізнес інформ. - 2016. - № 7. C. $163-169$.

24. Рудая И. Л.

Аутсорсинг: методология и практика: монография / И. Л. Рудая. - Самара: Универсгрупп, 2009. - 230 c.

25. Сайфиева С. Н. Теоретические основы и эволюция развития аутсорсинга [Электронный ресурс] / С. Н. Сайфиева, М. А. Быкадоров // Журнал экономической теории. 2006. - № 3. - Режим доступа: http://www.ipr-ras.ru/articles/sajf-bik067-a.pdf. 